\title{
準輝石族の相転移
}

\section{Transformation in Pyroxenoids}

\section{山 中 高 光 (Takamitsu Yamanaka)*}

\begin{abstract}
Many kinds of phase transformations in pyroxinoids in the system, $\mathrm{CaO}-\mathrm{MnO}$ $\mathrm{FeO}-\mathrm{SiO}_{2}$, have been discussed on their crystal chemical and thermodynamical respect.

Mono-phase transition in $\mathrm{CaSiO}_{3}$ between wollastonite and pseudowollastonite is caused by changing configurations of octahedral cations and results in the transformation from a chain silicate to a ring silicate. Since a free energy of pseudowollastonite bearing other divalent cations than calcium seems to increase with those contents, wollastonite having more than a certain amount of them is directly melt without the transition to pseudowollastonite.

Polytypic transformation between wollastonite (1T) to parawollastonite (2M) was found to be induced by thermal sheer stress in the slab structure, and a certain type in $3 \mathrm{~T}$ and $7 \mathrm{~T}$ polytypes are thermodynamically stable.

A fanction $G(X)_{0}=x G_{1 T}+(1-x) G_{2 M}-f(x) T S(x)_{\text {sla b }}$ represents a free energy of the ordered slab structure and the last term takes a part to reduce thenergy of the structure compared with that of a disordered mechanical mixed structure.

Intracrystalline cation self diffusion in a octahedral bands causes the change of periodicity of silicate chains and bring about phase transition from rhodonite to bustamite.

Clinopyroxene, ferroan-johannsenite and manganoan-hedenbergite, made a thermal transition to bustamite at $1050^{\circ} \mathrm{C}$ for $120 \mathrm{hrs}$, in which a topotaxtic transformation between them was observed. On the basis of the study of stability regions of those phase as a function of temperature, schematical phase diagram has been discussed in the join between $\mathrm{CaMnSi}_{2} \mathrm{O}_{6}$ and $\mathrm{CaFeSi}_{2} \mathrm{O}_{6}$.
\end{abstract}

* 東京大学理学部鉱物学教室 


\section{1. まえがき}

結晶構造解析や電子顕微鏡による微細構造の観察などの研究は結晶化学や地球科学 に大きな貢献をしてきた。また高温 X線構造解析から結晶構造の動的な研究も多くな され更に，最近高温電子顕微鏡が開発され微細組織の熱変動も観察できるようになっ た。

原子やイオンが配列状態を変えて自由エネルギーのより低い配列に変る相転移につ いて色々な結晶相に関して, 高温形と低温形の構造を比較することから転移の機構 の推論がなされてきた。一方結晶変態についての運動論について色々な分野で, また 色々な方法で論ぜられるようになり（山中 1979）, 多種な結晶変態のカイネティクス が明らかにされつつある。

熱エネルギーを変態の起因力として，陽イオンの自己拡散や結晶内席交換反応によ って生ずる転移や, thermal sheer stress によるイオンの無拡散で転移が生ずるマル テンサイト変態などが準輝石族に見いだされる。本論では特に $\mathrm{CaO}-\mathrm{MnO}-\mathrm{FeO}-\mathrm{SiO}_{2}$ 系の準輝石中相での相転移について熱力学的考察を試みた。

\section{2. 準輝石の結晶化学}

準輝石は輝石と同様に, $\mathrm{Ca}, \mathrm{Mn}, \mathrm{Fe}$ (僅かに $\mathrm{Mg}$ )によって構成される八面体がband 構造を形成し，その band が並列し層状に配列している。 $\mathrm{SiO}_{4}$ の四面体は鎖状構 造を呈し，陽イオンの band を結合している。この $\mathrm{SiO}_{3}$ chain の周期の違いにより 分類されている(Liebau, 1962)。また八面体と $\mathrm{SiO}_{3}$ chain の相互の位置関係によっ て準輝石は二つのシリーズに大別される。つまり二つの八面体だけで band を構成し ているシリーズと, 一つの band が二つと, 三つの八面体の部分からなるシリーズに 分れる（竹内 1976; Takéuch et al. 1977)。前者には babingtonite, numdulite pectorite p serandite が属し，後者には wollastonite bustamite rhodonite pyroxmangite pyroxferroite ferrosilite III 等が属する。

$\mathrm{Ca}-\mathrm{Mn}-\mathrm{FeSiO}_{3}$ 系の準輝石では $\mathrm{Ca}$ イオンは三つの八面体が band の部分をなし ている原子位置に秩序分布する傾向がある。 $\mathrm{SiO}_{4}$ の四面体が大きな $\mathrm{Ca}$ の八面体と 結合する時, chainに kink が生じる。従って ( $\mathrm{Ca}, \mathrm{Mn}, \mathrm{Fe}) \mathrm{SiO}_{3}$ 中の $\mathrm{Ca}$ イオン の成分比によって chain の kink の出現度が異なり, これが chain の周期性を規定 している。また八面体 band をはさんで上下の $\mathrm{SiO}_{3}$ chain の相対位置から多形や多 型が表われる。Ca 成分が少なくなるにつれて $\mathrm{SiO}_{3}$ Chain は長周期になる。例えば 八面体が全て $\mathrm{Ca}$ イオンによって構成されている wollastonite や parawollastonite は三つの $\mathrm{SiO}_{4}$ 四面体だけで一周期をなし，Ca を全く含まない ferrosilite III は 9 つの四面体で一周期をなしている。 


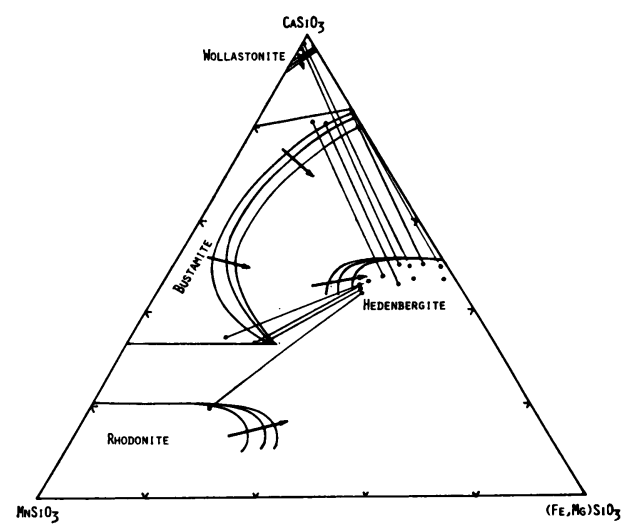

Fig. 1 Chemical composition of pyroxenoid solid solution.

As indicated by the arrow signs, at higher temperatures the stable regions of pyroxenoids are enlarged but that of clinopyroxene is shrinked.

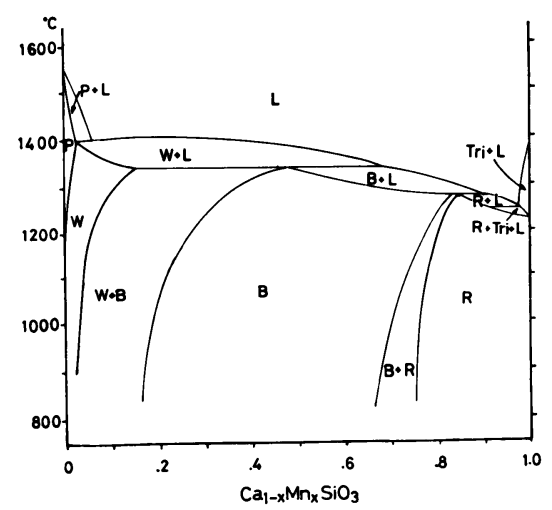

Fig. 2 Idealized phase diagram in the system between $\mathrm{CaSiO}_{3}-\mathrm{MnSiO}_{3}$.

johannsenite $\mathrm{CaMnSi}_{2} \mathrm{O}_{6}$ や hedenbergite $\mathrm{CaFeSi}_{2} \mathrm{O}_{6}$ 等の単斜輝石と異なり準 輝石相の各々はかなり広い固容領域を持つ事が明らかになってきた（南部他，1970； 南部他, 1977 ; Mason, 1975; Ohashi et al., 1974 5; Shimazaki et al., 1978)。そ れらを $\mathrm{CaSiO}_{3}-\mathrm{MnSiO}_{3}-\mathrm{FeSiO}_{3}$ 三成分系の三角図に総括すると Fig. 1 の如くなる。 準輝石の固溶領域は生成温度により変動し，その領域は図中の矢印の方向に拡大する 
と想像される。(Fig. 1 には単斜輝石との共生関係が表わしてある。)

相平衝合成実験からもこの系に関した相図が発表されている (Bowen et al., 1933; Glasser, 1962; 桃井, 1968; Rutstein, 1971)。これらの相図には不正確な部分が存 在することが構造解析などによって判明し再実験を要する。それらの事実す考慮し, $\mathrm{CaSiO}_{3}-\mathrm{MnSiO}_{3}$ 系の二成分系の模式的な相図を Fig. 2 に表わす。一方高圧実験か $ら \mathrm{CaSiO}_{3}$ (Huang et al., 1973; Kushiro, 1964) と $\mathrm{MnSiO}_{3}$ (Akimoto et al., 1972）の P-T 相図が発表されている。しかし固溶体についてはまだ不明である。

\section{3. 準輝石族間の相転移}

準輝石族の成分領域や構造の究明と共に，相互の構造転移実験も報告されてきた。 高温実験による熱転移や，高圧実験から圧転移の相関係が明らかにされてきた。それ らを Table 1 に総括した。これら以外に含水相からの脱水分解反応から準輝石が晶 出する相変態について xonotrite to wollastonite (Akimoto et al., 1972) innesite to rhodonite (Dent et al., 1956) などがある。

これらの相転移は次のように説明される。温度や圧力の変化により陽イオンで構成

Table 1 Transformation in Pyroxenoids

\begin{tabular}{|c|c|c|c|c|}
\hline Chemical formula & Low & $\begin{array}{l}\text { Temperature control } \\
\text { Temp. }\end{array}$ & High & Temp. \\
\hline $\mathrm{CaSiO}_{3}$ & \multicolumn{4}{|c|}{$\begin{array}{l}\text { wollas tonite (III) } \\
\left.\right|_{\text {parawollastonite (III) } b} b \text { pseudowollastonite (Ring) }\end{array}$} \\
\hline $\mathrm{Ca}_{1 / 2} \mathrm{Mn}_{1 / 2} \mathrm{SiO}_{3}$ & \multicolumn{4}{|c|}{ johannsenite $(\infty)-c$ bustamite (III) } \\
\hline $\mathrm{Ca}_{1 / 5} \mathrm{Mn}_{4 / 5} \mathrm{SiO}_{3}$ & \multicolumn{4}{|c|}{$\begin{aligned} & \text { rhodonite }(V)= d \\
& e \text { wollastonite (III) } \\
& \text { bustamite (III) }\end{aligned}$} \\
\hline $\mathrm{MnSiO}_{3}$ & \multicolumn{4}{|c|}{ pyroxmangite $(V I I) \longrightarrow \frac{f}{f}$ rhodonite $(V)$} \\
\hline $\mathrm{Ca}_{1 / 2} \mathrm{Fe}_{1 / 2} \mathrm{SiO}_{3}$ & \multicolumn{4}{|c|}{ hedenbergite $(\infty)-\frac{g}{\text { ferrobustamite (III) }}$} \\
\hline
\end{tabular}

\begin{tabular}{|c|c|c|c|c|}
\hline & \multicolumn{4}{|c|}{ Pressure control } \\
\hline & High & Press. & Low & Press. \\
\hline $\mathrm{CaSiO}_{3}$ & \multirow{3}{*}{\multicolumn{4}{|c|}{$\begin{array}{l}\text { High-pressure wollastonite (Ring) } h \text { wollastonite (III) } \\
\text { garnet } \underline{\underline{i}} \text { clinopyroxene }(\infty) \underline{i} \text { Pyroxmangite (VII) } \underline{i}_{\text {rhodonite }} \text { (V) } \\
\text { orthoferrosilite }(\infty) \stackrel{j}{c} \text { clinoferrosilite }(\infty)+\dot{j} \text { ferrosilite-III (IX) }\end{array}$}} \\
\hline $\mathrm{MnSiO}_{3}$ & & & & \\
\hline $\mathrm{FeSiO}_{3}$ & & & & \\
\hline
\end{tabular}

a. Jeffery et al (1953), Yamanaka et al ( in preparing) b. Trojer (1968), Wenk (1969) c. Morimoto et al (1966) d. Glasser (1961) e. Present work $f$. Aikawa (1979) g. Rapoport et al (1973) $h$. Trojer (1969) i. Ak1moto et al (1972), Ringwood et al (1967), j. Burnham (1966) 
される band の膨脹や収縮が生じ, 酸素イオンのパッキングが変動する。これらの変 化に伴って, band を結合している $\mathrm{SiO}_{3}$ のchain は伸縮する。しかし chain の伸縮 には限界があり，その限界を越えて陽イオン band が変化すると chain の周期の異な る構造に転移する。

Zoltai (1961), Bragg (1965), Liebau (1972) 等は輝石や準輝石では chain 構造 が “Building stone”と考え，陽イオンは二次的に chain の間隙を充填すると考えた。 しかし前述したように陽イオンのイオンサイズが chain configulation を規定すると 思われる。陽イオンの変動により chain は容易に tilt することが準輝石の特徴であ り (Yamanaka et al., 1977; Ohashi et al., 1978), それによって広い固溶領域が生 ずる。原子半径のかなり異なる $\mathrm{Ca}$ と $\mathrm{Mn}, \mathrm{Fe}$ が容易に置換するのは，八面体 band や $\mathrm{SiO}_{3}$ chain が非常に flexible であるためであろう。図 2 から明らかなように, 固 溶限界の近傍の成分を持つ場合, 成分を変えずに温度変化によって相変態させること が可能になる。

\section{3. -1 wollastonite-pseudowollastonite 転移}

これは chain silicate から ring silicate に転移する現象である。この現象につい て自由エネルギーの温度曲線（圧力一定）を, 一成分系の相変態の現象として検討し てみる。低温で安定な chain silicate 相 $(\mathrm{W})$ と高温安定型の ring silicate 相 $\left(\mathrm{P}_{\mathrm{S}} \mathrm{W}\right)$, また液相 $(\mathrm{L})$ の自由エネルギーの温度変化によって転移現象は異なる。 $\mathrm{P}_{\mathrm{S}} \mathrm{W}$ 相のエ ントロピーはW相のそれより大きく，L 相のそれより小さいため $\mathrm{S}_{\mathrm{W}}>\mathrm{S}_{\mathrm{P}_{\mathrm{S}} \mathrm{W}}<\mathrm{S}_{\mathrm{L}}$ で ある。エントロピーは $\left(\frac{\partial \mathrm{G}}{\partial \mathrm{T}}\right)_{\mathrm{P}}=-\mathrm{S}$ で表わすように $(\mathrm{G}-\mathrm{T})$ 四に於て自由エネルギー 曲線の傾きとなり， $\mathrm{P}_{\mathrm{S}} \mathrm{W}$ 相の自由エネルギーは温度が高くなるにつれて，W相に比 して急激に減少する。その結果ある温度 $\left(\mathrm{T}_{\mathrm{tr}}\right)$ で両相の自由エネルギー曲線は交叉す る。即ち $\mathrm{T}_{\mathrm{tr}}$ が転移点となる。温度が更に上がると $\mathrm{P}_{\mathrm{S}} \mathrm{W}$ 相の自由エネルギー曲線 は L 相の曲線と温度 $\mathrm{T}_{\mathrm{m}}$ で交叉する。この温度以上では融解する。Woll-Pseudo woll の関係は Fig. 3-A の G-T 図に表わす関係にある。

wollastonite は高温では Mn や Fe を10\%近く固溶するが，後述するように， pseudowollastonite では固溶しないため，W 相の自由エネルギー曲線が Fig. 3-B に示すように相 $\mathrm{P}_{\mathrm{S}} \mathrm{W}$ のそれと交叉するより低温で $\mathrm{L}$ 相のそれと交叉し, 転移温度 $\left(\mathrm{T}_{\mathrm{tr}}\right)$ が融点 $\left(\mathrm{T}_{\mathrm{m}}\right)$ より高くなるため, $\mathrm{P}_{\mathrm{S}} \mathrm{W}$ が安定になる前に $\mathrm{W}$ 相が融解し, 温 度を上げても転移は生じない。

pseudowollastonite の構造（図 4) は Ca の八面体の層構造の “void space”に $\left(\mathrm{SiO}_{3}\right)_{3}$ の三員環が存在し，それらが上下の層を接合させ，四層構造を呈している。 (Yamanaka in preparalion) 三員環が八面体の隅共有するためには充分大きな陽イ オン八面体でなければならず, $\mathrm{Mn}^{2+}, \mathrm{Fe}^{2+}$ の八面体ではそれを満足しえない, 従っ 


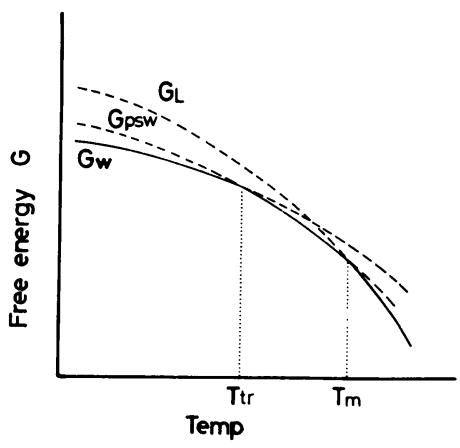

A

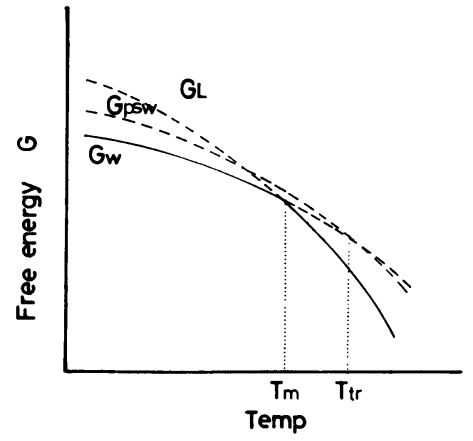

B

Fig. 3 Free energy diagram $(\mathrm{G}-\mathrm{T})$ of wollastonite, pseudowollastonite and liquid phases having a composition of $\mathrm{CaSiO}_{3}$.

Diagram A showing a phase relation in a pure $\mathrm{CaSiO}_{3}$ phase indicates the phase transition from wollastonite to pseudowollastonite at temperature of $\mathrm{T}_{\mathrm{tr}}$ but wollastonite bearing other divalent cations such as $\mathrm{Mn}$ or $\mathrm{Fe}$ is directly melt without the transition, as seen in the diagram $B$.

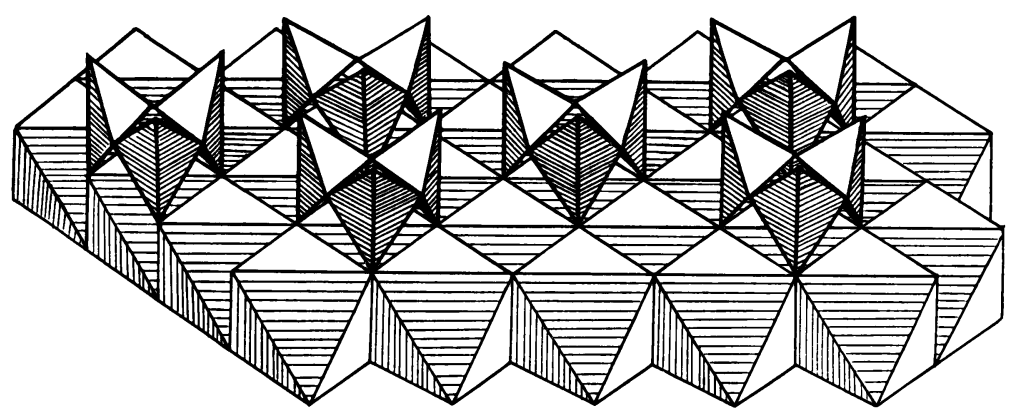

Fig. 4 Relative position of ternary silicate rings and octahedral layer in the pseudowollastonite structure.

て pseudowollastonite の構造はそれらのイオンを殆んど固溶しない。一方 wollastonite 構造では $\left(\mathrm{SiO}_{3}\right)_{3}$ chain の四面体間の $\mathrm{Si}-\mathrm{O}-\mathrm{Si}$ の角度を変える許容度がか なりあるため, Ca イオンに比して充分小さい $\mathrm{Mn}, \mathrm{Fe}$ イオンをある程度固溶させる ことができる。

chain silicate から ring silicate に転移する機構を, 両者の構造を比較して考察し 
てみると wollastonite の八面体 band が集合して, pseudowollastonite の八面体層 を形成し，それに伴つて $\left(\mathrm{SiO}_{3}\right)_{3}$ chain は kink site を中心にして三つづつ離脱し それらがそれぞれ三員環を形成することによって推移していくと考えられる。徉って woll. と pseudowoll は結晶学的に方位関係が依持され，いわゆる “topotactic transformation”が想像される。しかし単結晶の固体がそのまま高温で pseudowoll. に 転移する事実は確認されていない。両者の構造の体積変化が非常に大きいため, 単結 晶固体のまま転移は不可能で, 微細粒に分解し, 再配列し転移すると思われる。高温 電子顕微鏡を用いて転移実験を行うと方位関係を依持して pseudowoll. 相が成長す る状態が確認される。

\section{3. -2 wollstonite-parawollastonite 転移}

wollastonite と parawollastonite とは多型構造で, 前者は三斜 (1T) で後者は単 斜 $(2 \mathrm{M})$ 構造である。前者の $1 \mathrm{~T}$ スラブが chain 方向に b/2 単位胞がずれると後 者の構造になる (Trojer et al., 1968)。これらの構造の安定関係はまだ明確でない。 しかし parawollastonite の加熱試料の X 線回折図や高温電子顕微鏡による実験（山 中， 1977）からこの秩序構造は thermal sheer stress により disordered-wollastonite や twinned-wollastonite が生じる。（具体的なカイネティクスについては既報

（山中 1979）したので記述しない。）これは原子の熱振動が sheer stress の起因と なり，個々の単位胞が $\mathrm{b}$ 軸方向に slip を起こし原子の拡散を介在せず，マルテンサ イト変態を起す。

無秩序状態の wollastonite は機械的な混合体と考えられ，即ち $1 \mathrm{~T} と 2 \mathrm{M}$ の混合 相と見なせる。しかし disordered wollastonite の電子線回折から完全に無秩序構造 である場合と, 回折点に diffuse maximum が見いだされる場合がある。いくつかの 多型が確認される。特に $3 \mathrm{~T}$ や $2 \mathrm{~T}$ 構造を表わす回折点に強い強度が見い出される。 また格子縞や格子像にも3T 構造が確認されることが多い（山中，1979；Akai,1975； Wenk, 1976)。X 線でも 4T, twined-1T の他に3T と 7T (Hemmi et al., 1978)の 多型が確認されている。

このように準無秩序構造にいくつかの存在確率の高い多型があるということは，そ れらの構造が他に比して多少なりとも熱力学的に安定と考えられ得る。即ちそれらの 自由エネルギー $\mathrm{G}(\mathrm{X})$ （X は $1 \mathrm{~T}$ と $2 \mathrm{M}$ の存在分率）に極小值が幾つか有ると想像さ れる。

個々の多型の個体数は Table 2 に示す。

個々の多型に属する個体についても安定性に差異が存在すると想像される。しかし それらは小さいと思われる。

多型構造の熱力学的な研究は殆んどなされていないと言っても過言では無いだろ う。ここで wollastonite の多型についての実験事実にもとついて考察してみる。 
Table 2 Example of the number of wollastonite polytypes.

\begin{tabular}{ccc|ccc}
\hline 多型 & 個体数 & $1 \mathrm{~T}: 2 \mathrm{M}$ & 多型 & 個体数 & $1 \mathrm{~T}: 2 \mathrm{M}$ \\
\hline $3 \mathrm{~T}$ & 1 & $2: 1$ & $6 \mathrm{~T}$ & 1 & $5: 1$ \\
$4 \mathrm{~T}$ & 1 & $3: 1$ & & 2 & $4: 2$ \\
$4 \mathrm{M}$ & 1 & $1: 2$ & $6 \mathrm{M}$ & 3 & $3: 3$ \\
$5 \mathrm{~T}$ & 1 & $4: 1$ & $7 \mathrm{~T}$ & 1 & $6: 1$ \\
& 2 & $3: 1$ & & 3 & $5: 5$ \\
& & & & 5 & $4: 3$ \\
\hline
\end{tabular}

純粋に機械的混合相は $2 \mathrm{M}$ と $1 \mathrm{~T}$ のスラッブ構造が完全に無秩序分布をし両者の 分率に伴う自由エネルギ一変化は単純に $1 \mathrm{~T}$ 及び $2 \mathrm{M}$ 相の自由エネルギー $\mathrm{G}_{1 \mathrm{~T}}, \mathrm{G}_{2 \mathrm{M}}$ の相加として表現できる。

$$
\begin{aligned}
\mathrm{G}(\mathrm{X})_{\mathrm{d}} & =\mathrm{XG}_{1 \mathrm{~T}}+(1-\mathrm{X}) \mathrm{G}_{2 \mathrm{M}} \\
& =\mathrm{XH}_{1 \mathrm{~T}}+(1-\mathrm{X}) \mathrm{H}_{2 \mathrm{M}}-\mathrm{T}\left(\mathrm{XS}_{1 \mathrm{~T}}+(1-\mathrm{X}) \mathrm{S}_{2 \mathrm{M}}\right)
\end{aligned}
$$

しかし秩序型周期構造では

$$
\mathrm{G}(\mathrm{X})_{0}=\mathrm{XG}_{1 \mathrm{~T}}+(1-\mathrm{X}) \mathrm{G}_{2 \mathrm{M}}-\mathrm{f}(\mathrm{X}) \mathrm{TS}_{\mathrm{slab}}
$$

となりスラブ配列のエントロピー項 $\left(\mathrm{S}_{\mathrm{slab}}\right)$ が加わる。その結果, 機械的混合相の $\mathrm{G}(\mathrm{X})_{\mathrm{d}}$ より低い $\mathrm{G}(\mathrm{X})_{0}$ がある温度範囲で存在すると考えられる(Fig. 5)。その結果 同じ周期でも異った多型では異っ た $\mathrm{G}(\mathrm{X})_{0}$ を持ち安定性は違って くる。実際に見い出される3T は (AAB), (Akai et a.l, 1925), 7T は (AABABAB) (Hemmi et al., 1978)の積層であり，それらは3T や 7Tに属する他の多型に比して 安定であると想像される，これは $\mathrm{f}(\mathrm{X})$ によって制御される。

wollastonite の多型は前記した 数種が報告されているが，今後見 い出されるとすれば例えば 5T や $9 \mathrm{~T}$ では $(\mathrm{AABAB})$ や $(\mathrm{AABAB}$ $\mathrm{ABAB})$ の構造型であろうことが 図 5 から推論される。

このような熱力学的還境で成長

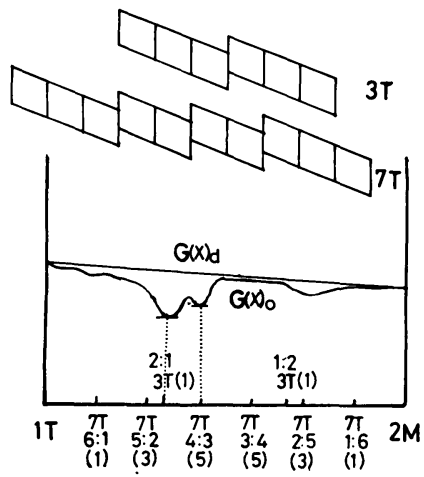

Fig. 5 Free energy of polytypes of the ordered slab. In a certain temperature range, the free energy of the ordered slab has a minimum at a compositional ratio $(x)$ of $1 T$ and $2 M$ due to the term, $f(x)$ $\mathrm{TS}(\mathrm{x})_{\mathrm{Slab}}$ (C. F. discussion). 
した wollastonite（例えば，岡山県，布賀）には秩序型周期構造が出現する可能性が ある。

現在合金，固溶体，などのように多元素の混合や，秩序度について熱力学で説明さ れるが鉱物結晶に特異なスラッブ構造の秩序度に関する熱力学的考察は皆無に等し い。このような研究は大変興味あるテーマである。

\section{3. -3 準輝石と単斜輝石間の転移}

前述したように準輝石と輝石では八面体 band と $\mathrm{SiO}_{3}$ chain の結合の仕方が部分 的に異なるだけで, 相互に似た部分構造がある。従って準輝石と輝石は容易に転移を 起こすことが想像できる。低温安定形の単斜輝石 johannsenite が $830^{\circ} \mathrm{C}$ で bustamite に転移する (Schaller, 1938), ‘たこの転移は陽イオンの密なゾーンが保存さ れる topotaxy が依持される転移の機構が論ぜられている (Morimoto et al., 1966)。 hedenbergiteもまた ferrobustamite に $960^{\circ} \mathrm{C} て ゙$ 転移することが述べられている。 しかし Mn スカルン鉱物中に広範に産出する batasmite の生成温度が上記実験結果 ほど高温とは思えない (Shimazaki et al., 1978)。この点再実験が必要である。

johannsenite から hedenbergite に至るまで, 連続固溶体 $\mathrm{Ca}(\mathrm{Mn}, \mathrm{Fe}) \mathrm{Si}_{2} \mathrm{O}_{6}$ が 成立すると考えられている（南部他，(1970; 南部他。1977; Ohashi et al., 1978)。 これらの固溶体中の単斜輝石から準輝石への転移実験は興味ある問題である。さらに bustamite と hedenbergite の共生の記載例は少ないが, Fig. 1に示すように hedenbergite と woll. bust. ferrobust. rhodo. や pyroxmangite との共生が報告されて おりここれらの共生関係についてもまた興味ある問題である。

ferroan-johannsenite（秩父, 赤石産）と manganoan-hedenbergite（島根県, 笹 ヶ谷産）を用いて転移実験を行ってみた。両試料とも真空加熱処理 $\left(1050^{\circ} \mathrm{C}, 120\right.$ 時 間）するとそれぞれ母相の単斜輝石の長柱状の方向をほぼ依持した bustamite と ferrobustamite が確認される。とくに hedenbergite から ferrobustamite への転移 では，母相と転移相との topotaxy は明確である。加熱前後の各試料の成分を三角成 分図（Fig. 6) に表わすと転移相の成分は母相のそれに比して著しく分散している。 ferrobustamite 相の成分では, $\mathrm{Mn}$ と Fe が, bustamite 相では, Ca と (Fe, Mn) がほぼ相関を持って成分変動することが認められる。しかしこの結果は実験温度での 平衝状態を表わしているのではない。固相夜相間での固相線に沿う固溶体と異なり, 固相固相間で起る固溶体であるため, 固相内の原子の拡散のカイネティクスが実験で は考虑されねばならない。それらの概論については“結晶変態のカイネティクス”を 参照されたい。

温度が上昇するにつれ，Cpx は $\mathrm{G}(\mathrm{X})$ の違いによって固相線に沿って Fe 成分に 富んだ相へ移行しようとする“driving force”を持つ, それに伴って bustamite の 


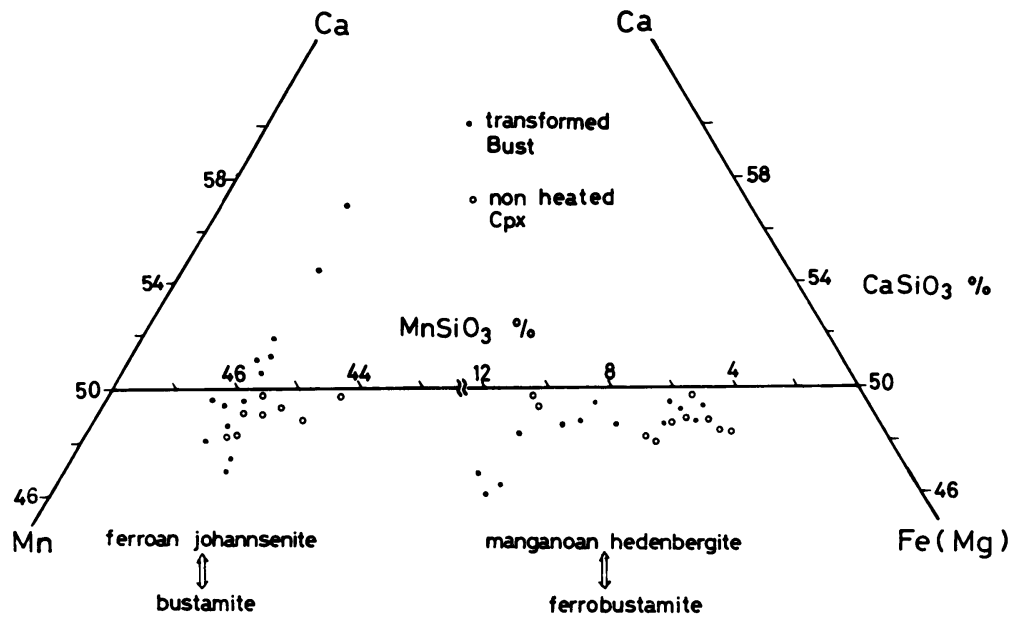

Fig. 6 Variation of chemical compositions of the inverted bustamite from ferroan-johannsenite and the inverted ferrobustamite from manganoan-hedenbergite.

固相線上の成分を持った核がつくられるであろう。形成された核はその後温度上昇に つれ， $\mathrm{Cpx}$ を費しつつ成長する。この状態は構造的には clustering として表われ る。Cpx の原子の拡散と分解, それに伴う bustamite の成長と固体内拡散が同時に 起る。それらの速度は一様でないため, 母相や転移相に成分の異った cluster（充分 大きく成長したもの）が生じる。一成分系の転移や，固液界面を介在する固溶体の変 態と異なり，固相 $\rightarrow$ 固相転移しかも両者ともに固溶体の場合は実験として，特に充分 な時間を要しないと平衝論は論じることはできない。したがって Fig. 6 は非平衝状 態の成分変動と見なせる。

Fig. 1 や Fig. 6 さらに合成実験（未発表）をもとに $\mathrm{CaMnSi}_{2} \mathrm{O}_{6}-\mathrm{CaFeSi}_{2} \mathrm{O}_{6}$ の 相平衝を想定すると Fig. 7-C の如くなる。理想溶液型固溶体 (Fig. 7-A) とは大き く異なる，また bustamite と $\mathrm{Cpx}$ ともに低温では Fe の固溶度 $\left(\mathrm{X}_{\mathrm{A}}\right)$ の少ない所 で自由エネルギー曲線 (G-T図) に極小值があり，高温では両者の極小值は成分 $\mathrm{Fe}$ に富む $\mathrm{X}_{\mathrm{B}}$ に移行する，しかし bustamite 相ではかなり高温までこの変動は小さく ある温度以上では急激に移行する。その結果, 相図 (X-T) は Fig. 7-C となる, 両 相の温度 $\mathrm{T}_{1}-\mathrm{T}_{2}$ 間での $\mathrm{Mn}$ と $\mathrm{Fe}$ の成分変動幅も $\mathrm{b}_{1}-\mathrm{b}_{2}$ と $\mathrm{c}_{1}-\mathrm{c}_{2}$ となり固溶領域の 広い manganoan hedenbergite が晶出することとなる。

スカルン鉱物に見い出される bustamite は図 2 に示すように $\mathrm{Ca}_{0.8} \mathrm{Mn}_{0.2} \mathrm{SiO}_{3}$ から $\mathrm{Ca}_{0.35} \mathrm{Mn}_{0.65}$ まで $\mathrm{Ca}$ と $\mathrm{Mn}$ に関して広い固溶領域をもつが hedenbergite や jo- 


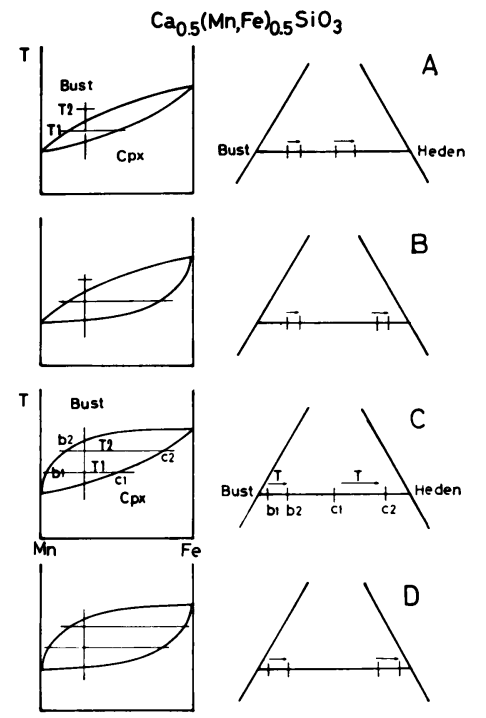

Fig. 7 Schematical diagrams of the solid solutions of bustamite and clinopyroxene in the binary system $\mathrm{CaMnSi}_{2} \mathrm{O}_{6}$ and $\mathrm{CaFeSi}_{2} \mathrm{O}_{6}$.

Diagram $\mathrm{A}$ represents an ideal solution model and diagram $\mathrm{C}$ in nonideal solution models is the most reasonable one for the experimental facts.

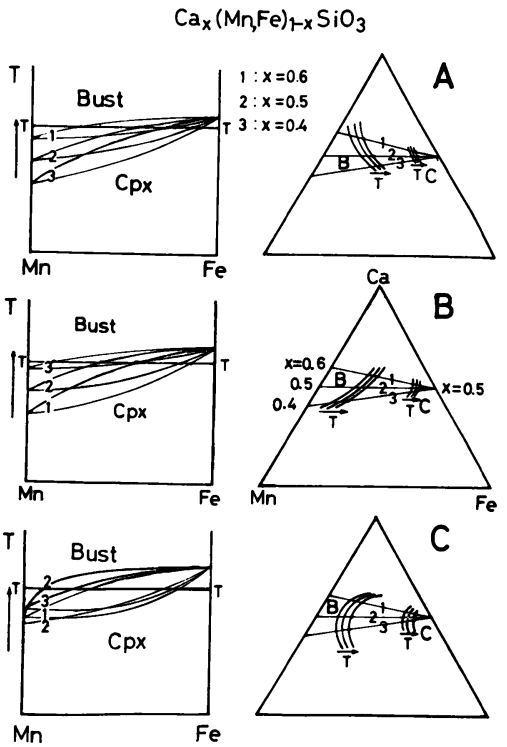

Fig. 8 Schematical diagrams of a solid solution $\mathrm{Ca}_{\mathrm{x}}(\mathrm{Mn}, \mathrm{Fe})_{1-\mathrm{x}} \mathrm{SiO}_{3}$ in bustamite and clinopyroxene. The most probable diagram should be diagram $\mathrm{C}$ from the view poit of chemical compositions of natural specimens and their localityies.

hannsenite の $\mathrm{Cpx}$ で $\mathrm{Ca}$ と $(\mathrm{Mn}, \mathrm{Fe})$ の固溶は殆ど認められない。（スカルン鉱物 以外では多少前者は固溶体を作る)。実際の鉱物共生を考えるためには，前記の二成 分系の相図を拡張する必要がある。つまり固溶体 $\mathrm{Ca}_{\mathrm{x}}(\mathrm{Mn}, \mathrm{Fe})_{1-\mathrm{x}} \mathrm{SiO}_{3}$ の $\mathrm{Cpx}$ と bustamite の相平衝図は Fig. 7 に関連して $\mathrm{Ca}_{\mathrm{X}} \mathrm{Mn}_{1-\mathrm{X}} \mathrm{SiO}_{3}$ と $\mathrm{CaFeSiO}_{3}$ 間の固溶 体を考えれば良いことになる。Fig. 1 や Fig. 6，また合成実験などから Fig. 8-A， B, C が考えられるが，とくに Fig. 8-C が諸々の事実と矛盾しないと思われる。現 在この系に関する三成分系の相図は確立されていないがこれは必要欠くべからざる相 困の一つであろう。

\section{3. -4 Bustamite-Rhodonite 転移}

準輝石族中で chain の周期の異なる構造間でも熱転移が生じる，例えば pyroxma- 
gnite から rhodonite への転移は低温で $\left(\mathrm{SiO}_{3}\right)_{7}$ の chain が高温で $\left(\mathrm{SiO}_{3}\right)_{5}$ の短い 周期の構造へ転移する（Aikawa, 1979)。またに Ca 富んだ rhodonite は $\left(\mathrm{SiO}_{3}\right)_{3}$ の短い bustamite へ高温で転移する。

Glasser 等(Glasser et al., 1961) は rhodonite は $1150^{\circ} \mathrm{C}$ で数分間で wollastonite に転移することを X 線 oscilation カメラで確認したと報告したが, bustamite と wollastonite はX 線回折図が極似している回折面(hkl)があるための誤認であろろ。

Fig. 1 と Fig. 2 のように bustamite と rhodonite 間には不混合領域が存在し前 者では $\mathrm{Ca}_{1 / 3} \mathrm{Mn}_{2 / 3} \mathrm{SiO}_{3}$ 成分まで $\mathrm{Ca}$ が固溶し，後者では $\mathrm{Ca}_{1 / 5} \mathrm{Mn}_{4 / 5} \mathrm{SiO}_{3}$ 成分から Mn をより多く固溶する。しかし Fig. 2 に示す如く，Ca に富んだ rhodonite は高 温で bustamite へ変態することは想像される。topotactic に転移する場合，母相と転 移相との界面の整合度により難易度は異なり，準輝石間の転移では八面体 band に垂 直な面で両相がほぼ半整合界面を持つ。この界面を基準にして再配列をしながら転移 は伝波する。そして原子の移動距離はできるだけ小さい事がこのような転移では要求 される。以上から八面体のサイズができるだけ近似し得る構造へょり容易に転移す

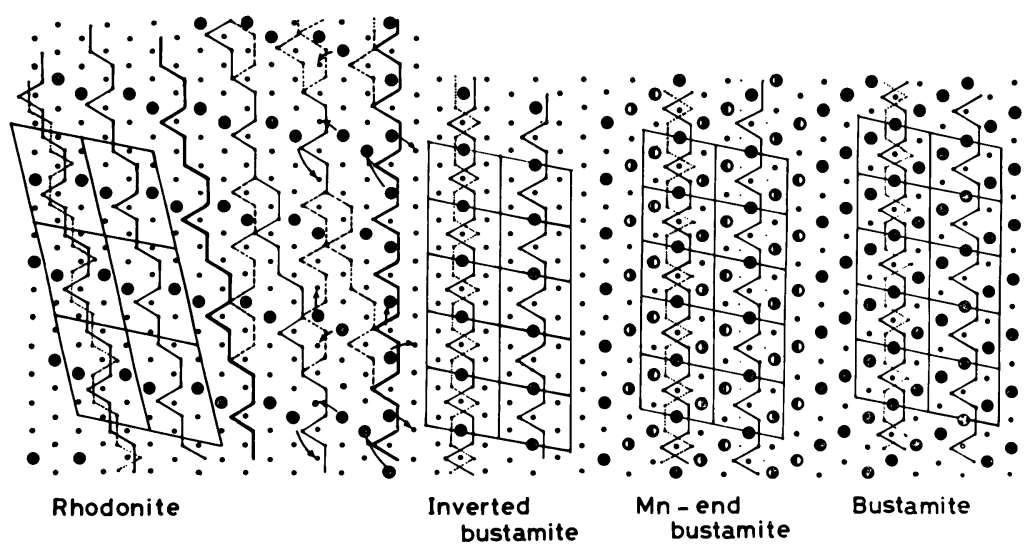

Fig. 9 Schematical cation distribution and silicate chain in rhodonite (A), inverted bustamite (C), Mn-richest natural bustamite (D) and ideal bustamite (E).

The large and small solid circles indicate $\mathrm{Ca}$ and $\mathrm{Mn}$ atoms, respectively. The half solid circles represent half $\mathrm{Ca}$ and half Mn occupancy. Silicon positions are linked by solid lines, and those under octahedral layer are partly linked by dotted lines. The arror signs in the region of $(B)$ indicate the intracrystalline exchange of large cation, $\mathrm{Ca}$, in the octahedral layer during the transformation from rhodonite to inverted bustamite. 
る。 wollastonite と bustamite を比較すると後者の構造へ rhodonite は転移しやす い。これは前述した相図からの推論とも一致する。

天然の bustamite は $\mathrm{Ca}_{1 / 3} \mathrm{Mn}_{2 / 3} \mathrm{SiO}_{3}$ が固溶限界であるが，構造上, site-occupancy を考えると, $\mathrm{Ca}_{1 / 6} \mathrm{Mn}_{5 / 6} \mathrm{SiO}_{3}$ まで伸びる可能性がある。

rhodonite（岩手県, 野田玉川産, $\mathrm{Ca}_{0.18} \mathrm{Mn}_{0.76} \mathrm{Fe}_{0.01}$ ) $\mathrm{SiO}_{3}$ を $1200^{\circ} \mathrm{C} \pm 5^{\circ} \mathrm{C} 48$ hour 真空加熱後急冷した試料について, 単結晶構造解析した結果は予想通り bustamite 構 造であった。この inverted-bustamite は天然結晶と異なり陽イオンサイト中でのCa, Mn の分布は秩序度が極端に悪い(Yamanaka et al., in preparation)。この構造の 格子定数と密度は bustamite の固溶体の成分変化に伴うそれらの変化の延長上に位 置している。

chain の周期を変える転移機構について, chain 構造が準輝石の ,Building stone” であるという立場から “Silicon migration”(Dent et al., 1956, Glasser et al., 1961) で説明されたが，前述のように八面体の陽イオン分布が chain が周期を規定すると考 える方が妥当であるため, それに基づいて考えると Fig. 9 のようになる。即ち大き な $\mathrm{Ca}^{2+}(0.99 \AA)$ と小さな $\mathrm{Mn}^{2+}(0.80 \AA)$ が八面体バンド中, 相対的にどの位置をし めるかによって隅共有する $\mathrm{SiO}_{4}$ 四面体の kink の位置が変り, その結果周期が異な る。 rhodonite では $\mathrm{M} 5$ サイトに $\mathrm{Ca}^{2+}$ が秩序分布しているが，高温で無秩序分布 し, chainも $\left(\mathrm{SiO}_{3}\right)_{5}$ から $\left(\mathrm{SiO}_{3}\right)_{3}$ の周期に変ったと考えられる。

\section{4. まとめ}

準輝石族の一貫した結晶化学が明確になってきた現在, それら相互の転移について. そのカイネティクスや熱力学的考察についていくつかの例について論に゙たが，多くの 点で推論を重ねた。今後これらの分野の研究がのぞまれる。

\section{文献}

1) 山中高光 : 鉱物学雑誌, 14, 59-74 (1979)

2) Liebau, F. : Naturwissenschaften, 49, 481-491 (1962)

3) 竹内慶夫 - 小藤吉郎・山中高光 : 岩鉱誌特別号 1, 41-64 (1976)

4) Takéuchi, Y. and K. Koto : Mineral. Jour., 8, 272-285 (1977)

5）南部松夫 - 谷田勝俊・北村 強 : 選鉱製鍊研究所報告, 26, 123-132 (1970)

6）南部松夫・谷田勝俊・北村 強： " , 33, 31-42 (1977)

7) Mason, B. : Amer. Mineral., 60, 209-212 (1975)

8) Ohashi, Y., A. Kato and S. Matsubara : Carnegie Inst. Year Book, 561-564 (1974-5)

9) Shimazaki, H. and M. Bunno: Can. Mineral., 16, 539-545 (1978) 
10) Bowen, N. L., J. F. Schairer and E. Posnjak : Amer. Sci., 226, 193-284 (1933)

11) Glasser, F. P. : Amer. Ceram. Soc., 45, 242-249 (1962)

12) 桃井 斉 : 鉱物学雑誌, 8, 特別号 2, 2-5 (1968)

13) Rutstein, M. S. : Amer. Mineral., 56, 2040-2052 (1971)

14) Huang, W. L. and P. J. Wyllie: Amer. mineral., 60, 213-217 (1973)

15) Kushiro, I. : Carnegie Inst. Year Book, 63, 83-84 (1964)

16) Akimoto, and Y. Syono: Amer. Mineral., 57, 76-84 (1972)

17) Dent, L. S. and H. F. W. Taylor : Acta Cryst., 9, 1002-1004 (1956)

18) Ryall, W. R. and I. M. Threadgold : Amer. Mineral, 53, 1614-1634 (1968)

19) Zoltai, T. : Amer. Mineral., 45, 960-973 (1960)

20) Bragg, W. L., G. F. Claringbull and W. H. Tayler crystal structer of minerals (1965)

21) Yamanaka, T., R. Sadanaga and Y. Takéuchi : Amer. Miner., 62, 1216-1224 (1977)

22) Ohashi, Y. and L. W. Finger : Amer. Mineral., 63, 274-288 (1978)

23) Yamanaka, T., R. Sadanaga, Y. Takéuchi and H. Mori (in preparation)

24) Trojer, F.J : Zeit, Kristallogr., 127, 291-308 (1968)

25) 山中高光・今西康弘・定永両一 : 鉱物学会年会講演要旨集, 66-67 (1977)

26) Akai, J. : Men. Fac. Sci. Kyoto Univ., Series of Geol. and Miner. XLI, 1-14 (1975)

27) Wenk, H. R., W. F. Muller, N. A. Liddel and P. P. Phakey : Electron microsco. py in Mineralogy, 324-331 (1976)

28) Hemmi, C., I. Kusachi, A. Kawahara and K. Hemmi : Mineral. Jour., 9, 169187 (1978)

29) Schaller W. T. : Amer. Mineral., 23, 575-586 (1938)

30) Morimoto, N., K. Koto and T. Shinohara: Mineral, Jour., 5, 44-64 (1966)

32) Aikawa, N., Mineral. Jour., 9, 255-269 (1979)

33) Glasser, L. S. D. and F. P. Glasser : Acta. Crystallogr, 14, 818-822 (1961)

34) Yamanaka, T. and Y. Takéuchi (in preparation) 